Iranian Journal of Pathology | ISSN: 2345-3656

\title{
Non Secretory Multiple Myeloma With HCV Infection: A Rare Case Entity
}

ArunPuri, Heena Wadhwa*, Navtej Singh

Baba Farid University of Health Sciences, Faridkot, India

\begin{tabular}{c}
\hline KEYWORDS \\
\hline $\begin{array}{c}\text { Non Secretory; } \\
\text { Multiple Myeloma }\end{array}$ \\
\hline
\end{tabular}

\section{Article Info}

Received 17 Oct 2016; Accepted 05 April 2018; Published Online 17 July 2018;

\begin{abstract}
Multiple Myeloma is a neoplasm of B cell lineage characterized by excessive proliferation of abnormal plasma cells. It is characterized by a clinical pentad of 1) anemia, 2) a monoclonal protein in the serum or the urine or both, 3) bone leisons and or bone pain, 4) hypercalcemia $>11.5 \mathrm{~g} / \mathrm{dl}$ and 5) renal insufficiency. Non secretory multiple myeloma is a rare variant of the classic form of multiple myeloma and accounts for $1 \%$ to $5 \%$ of all cases of multiple myeloma. The clinical presentation and radiographic findings of non-secretory multiple myeloma and multiple myeloma are the same. The diagnosis of multiple myeloma requires the demonstration of monoclonal gammopathy in the serum or urine. In non-secretory multiple myeloma, however no such gammopathy can be demonstrated, making the diagnosis more difficult. We describe a 60 year old woman who initially presented with back pain which when further investigated by complete blood count revealed hemoglobin of $13 \mathrm{~g} / \mathrm{dl}$, Total Leukocyte Count of 10,890 and platelet count of $1.5 \mathrm{lac} / \mathrm{cmm}$. Viral markers revealed HCV positive. Hypercalcemia with a serum calcium level of $12.5 \mathrm{~g} / \mathrm{dl}$ was also demonstrated. MRI revealed multiple lytic bony lesions. No monoclonal gammopathy was found in the serum or urine and bone marrow biopsy showed marked plasmacytosis of $>45 \%$. We present a case of Non Secretory multiple myeloma because of its illusive nature and rare entity.
\end{abstract}

Corresponding information:

Heena Wadhwa, Junior Resident Pathology, Baba FaridUniversity of Health Sciences, Faridkot, India E-mail: heena.wadhwa31@gmail.com

Copyright (C) 2018, IRANIAN JOURNAL OF PATHOLOGY. This is an open-access article distributed under the terms of the Creative Commons Attribution-noncommercial 4.0 International License which permits copy and redistribute the material just in noncommercial usages, provided the original work is properly cited.

\section{Introduction}

Multiple myeloma (MM) is a neoplasm of B cell lineage characterized by excessive proliferation of abnormal plasma cells secreting a monoclonal paraprotein (M protein) which may be an immunoglobulin or one of its constituent chains (1).

It is the most common primary malignant tumor of the bone, about $27 \%$ of the biopsied bone tumors(7).

Nonsecretory multiple myeloma (NSMM) is by definition the absence of a detectable $\mathrm{M}$ protein in the serum and/or in the urine of a MM patient. It constitutes approximately $1-5 \%$ of all patients newly diagnosed with MM $(3,4,5)$.

Classical multiple myeloma is characterized by a clinical pentad of

- Anemia,
- A monoclonal protein in the serum or the urine or both,

- Bony lesions and or bone pain,

- Hypercalcemia $>11.5 \mathrm{~g} / \mathrm{dl}$

- Renal insufficiency

\section{International Working Group Criteria}

For active multiple myeloma

- Monoclonal protein present in the serum \& or In the urine.

- Clonal bone marrow plasma cells or plasmacytoma.

- Related organ or tissue impairment.

\section{Chronic Leukemia Myeloma Task Force}

If $M$ protein is present in serum or urine,

One or more of following should be present: 
- $\quad>500$ plasma cells/cumm in peripheral blood.

- Marrow plasmacytosis $>5 \%$ in absence of underlying reactive process.

- Tissue biopsy demonstrating replacement and distortion of normal tissue by plasma cells.

- Osteolytic lesion unexplained by other causes.

\section{Chronic Leukemia Myeloma Task Force}

\section{If $M$ protein is absent in serum}

Radiologic evidence of osteolytic lesions or palpable tumor and one or more of the following is required.

- Marrow plasmacytosis of $>20 \%$ from two sites in the absence of reactive process.

- Tissue biopsy demonstrating replacement and distortion of normal tissue by plasma cell.

\section{Case report}

The present case is of a 60 year old woman who initially presented with back pain. There was no history of trauma or history suggestive of any comorbid conditions.

Examination revealed tenderness on right side of lumbosacral spine and right sacroilliac joint. Hip movements were normal.

MRI scan showed wedge compression fracture of D6, D7, D9 \& D10 vertebrae with areas of altered signal intensity involving right sided pedicle of D9 \& D10 vertebrae compressing the thecal sac and dorsal spinal cord.

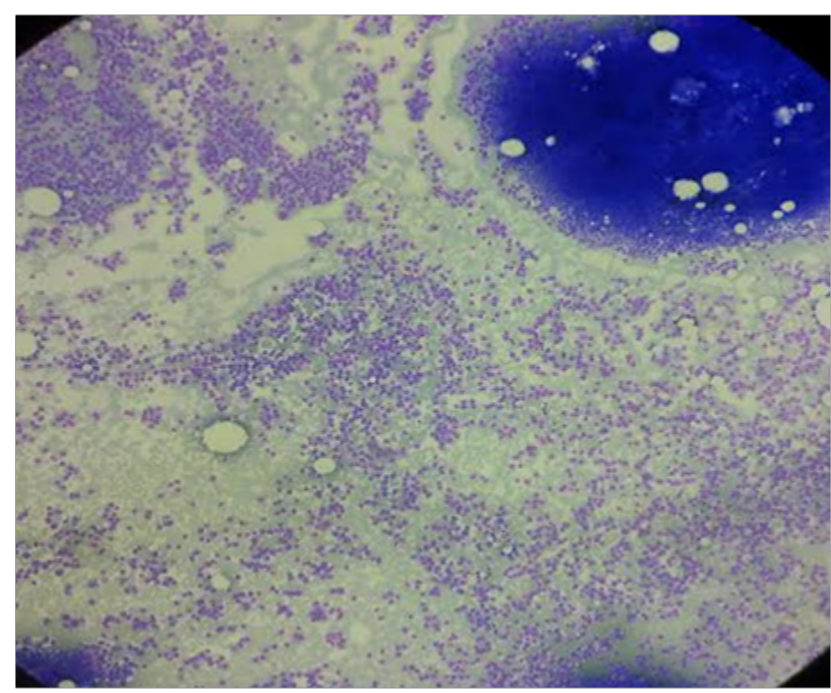

Bone marrow aspiration

10x magnification
Edema in dorsal spinal cord at D10 level was also noted.

\section{Lab investigations revealed}

- Hemoglobin of $13 \mathrm{~g} / \mathrm{dl}$,

- Total Leukocyte Count of 10,890 and

- Platelet count of $1.5 \mathrm{lac} / \mathrm{cumm}$.

- $\quad \mathrm{ESR}=27 \mathrm{~mm} / \mathrm{hr}$

- Viral markers revealed HCV positive( incidental finding).

- Hypercalcemia with a serum calcium level of $12.5 \mathrm{~g} / \mathrm{dl}$.

- PBF shows normal blood picture with mild neutrophilia(75\%) and no rouleaux formation .

- Bone marrow aspiration and biopsy revealed plasmacytosis $(>45 \%)$

- Serum protein electrophoresis showed absence of $\mathrm{M}$ band with hypogammaglobulinemia.

The above patient meets the criteria laid down by the international myeloma working group and chronic leukemia myeloma task force.

It was also a diagnostic dilemma as other disorders such as secondary deposits, osteoporosis and hyperparathyroidism can present with a similar picture.

Our patient did not undergo serum immunoglobulinfree light chain assay (FLC).

Now patient is currently being managed on the lines of treatment of multiple myeloma.

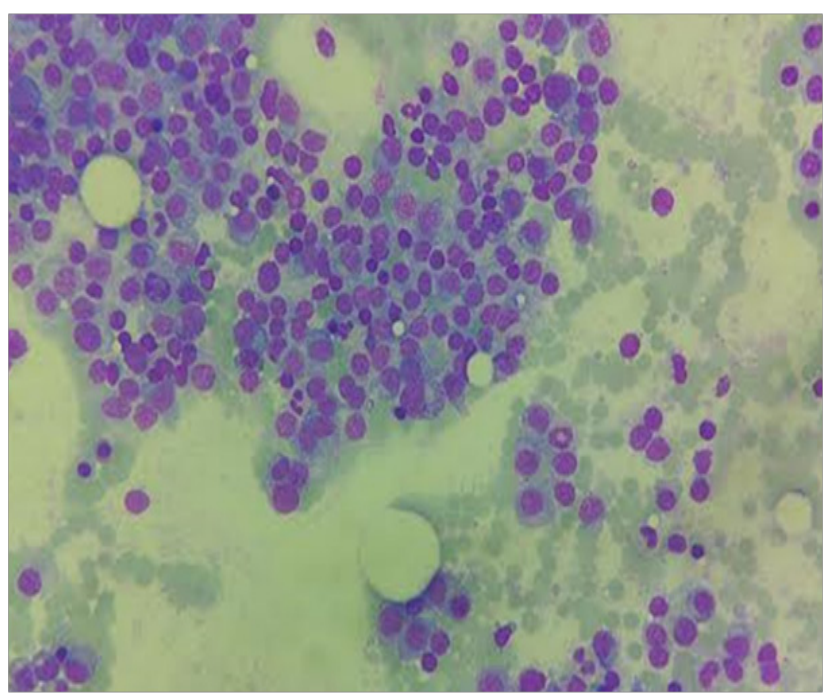

Bone marrow aspiration 40x magnification 


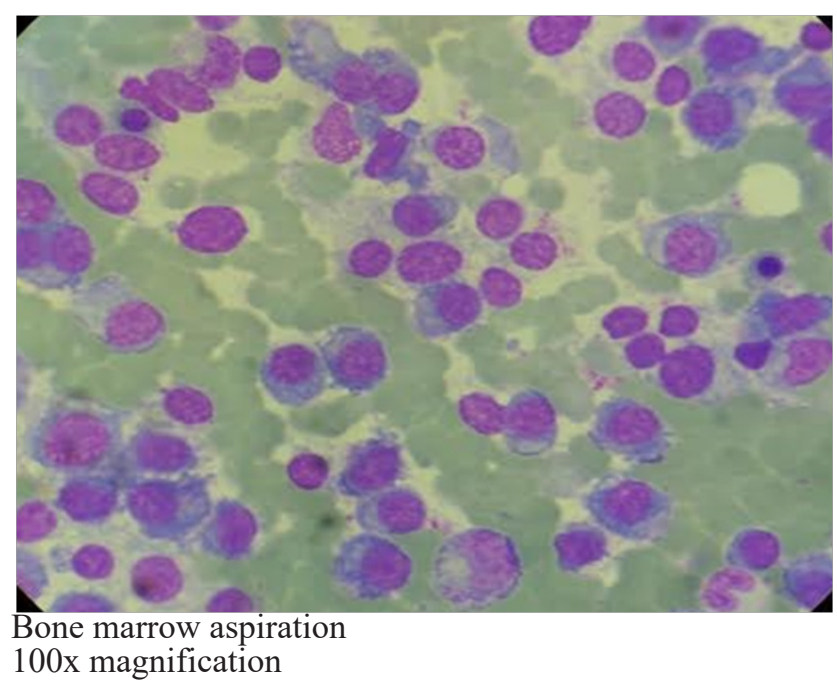

\section{Discussion}

Multiple myeloma is a disorder of the bone marrow which accounts for $10-15 \%$ of all blood cancers and one to two per cent of all malignancies $(3,4)$.

In the United Kingdom it accounts for 6.6 per 100,000 (5).

Among the varied presentation $10-40 \%$ is asymptomatic and $50-70 \%$ will have bony pain due to lytic lesions and pathological fractures (3).

A high index of suspicion should be kept in mind to avoid diagnostic delay.

Some researchers have further classified the nonsecretory myeloma based on the finding of intracytoplasmic immunoglobulin.

They separated them into two types - nonproducer type (about 15\%) where immunoglobulin was not found in plasma cells and in the remaining $85 \%$ called producer type the immunoglobulin is demonstrable in plasma cells but not in blood.

Whether this is of any prognostic significance remains to be proved in the absence of large volume of cases.

\section{Conclusion}

Arguments have been placed in earlier reports about patients with nonsecretory myeloma having better survival rates because of their early presentation and absence of renal insufficiency $(2,6)$.
However, there is bound to be some delay in diagnosis as they do not demonstrate the paraprotein in blood or urine which may shorten their survival (6).

Hence a high index of suspicion should be kept in mind. Once diagnosed, treatment remains the same as for multiple myeloma.

The response to treatment and the prognosis remains the same (6).

\section{Conflict of interests}

The authors declared no conflict of interest.

\section{References}

1. Iman A. Abdalla MD, Imad A. Tabbara MD. Nonsecretory Multiple Myeloma. South Med J. 2002;95(7):761-4.

2. Middela S, Kanse P. Nonsecretory multiple myeloma. Indian J Orthop. 2009;43(4):40811. https://doi.org/10.4103/0019-5413.55979 PMID:19838394 PMCID:PMC2762556

3. Smith DB, Harris M, Gowland E, Chang J, Scarffe JH. Non-secretory multiple myeloma: report of 13 cases with review of literature. Haematol Oncol. 1986;4(4):307-13. https://doi. org/10.1002/hon.2900040407

4. Kyle RA. Ask The Experts: Nonsecretory Myeloma. Myeloma Today. 2000;4:2.

5. International Myeloma Working Group. International Myeloma Working Group guidelines for serum-free light chain analysis in multiple myeloma and related disorders. Leuke- 
mia. 2009;23:215-24. https://doi.org/10.1038/ leu.2008.307 PMID:19020545

6. Greer JP, Arber DA, Glader B, List AF, Means RT, Paraskevas et al. Wintrobe's Clinical Hematology. Thirteen ed. Philadelphia. Lippincott
Williams \& Wilkins,a Wolters Kluwer business; 2014. chapter 98, Multiple Myeloma; 2046-97

7. Greenspan A, Remagen W. Differential Diagnosis of Tumors and Tumor-Like Lesions of Bones and Joints. Lippincott: Williams and Wilkins; 1998. p. 275.

\section{How to Cite This Article}

Puri A, Wadhwa H, Singh N. Non Secretory Multiple Myeloma With HCV Infection: A Rare Case Entity. Iranian Journal of Pathology, 2018; 13(2): 281-284. 